\title{
The Effect of Strategy Management and Balanced Scorecard on Organizational Performance of UAE Civil Defense
}

\author{
Saif Hassan Ali Alzaabi \\ Management Science University (MSU), Malaysia \\ UAE Civil Defense, Sharjah, U.A.E \\ E-mail: saifalmatroushi@hotmail.com \\ Hassan Al-Dhaafri \\ Assistant Professor, University of Dubai \\ Dubai Police, Dubai, United Arab Emirates \\ E-mail: Hassan_Saleh3@hotmail.com
}

Received: January 31, 2018

Accepted: February 11, 2018 Published: May 9, 2018

doi:10.5296/bms.v9i1.13112

URL: https://doi.org/10.5296/bms.v9i1.13112

\begin{abstract}
The main purpose of this study is to investigate the effects of Strategy Management (ST) and Balanced Scorecard (BSC) on Organizational Performance (OP). Based on a theoretical foundation and a wide review of the literature, the model of the research was proposed. 220 Questionnaires were distributed among random selected sample of Civil Defense departments in the Northern Emirates. 188 questionnaires were returned and used in the analysis using the PLS-SEM. The results of this study demonstrate that Strategy Management and Balanced Scorecard have positive and significant effect on Organizational Performance. This study reflects the importance of the right implementation to the strategy management and BSC to have successful performance. This study also supported the premises of the resource-based view theory by reaffirming the importance of the Strategy Management and BSC as drivers to enhance organizational performance.
\end{abstract}

Keywords: Strategy Management (ST), Balanced Scorecard (BSC), Organizational Performance (OP) 


\section{Introduction}

The measures set out by the civil defense can be summarized into four major operations, which are prevention, protection, fire, emergency and crisis plans and were employed as an interlocutor sector strategy. The sector's organizational structure was designed to match the effective and efficient achievement of major processes based on the audit committee's review and update. The fifth major operation that dealt with the resources and supported services was included by the Council's adoption at the end of 2014 to develop updates on the 2015 organizational structure.

At the local level, the civil defense partners include the entire police sectors of the Interior Ministry in prevention, protection, fire, emergency and crisis plans operations. Added to this are the federal and local bodies and relevant institutions to the prevention processes, and the armed forces in operations of crises and emergency plans.

At the regional level, its partners include the leaders of the civil defense of the GCC and at the global level, its partner are civil defense leaders from London, Singapore, Venezuela, Paris, New York and Germany, and several other international organizations that deal with civil defense (e.g., NFPA).

Several beneficiaries have been outlined for the services of civil defense and these include; at the fire, emergency plans and crisis operations level, all the UAE buildings and facilities, and societal segments. At the prevention level, UAE consultants and construction contractors, the UAE public and private facilities and privet properties, the UAE asylum commercial and industrial licenses, and the asylum-trading civil defense equipment adoption in the form of factories, agents, distributors and laboratories. At the protection level of operations, all the public and private building in the UAE with the inclusion of private and government departments and institutions, residential buildings, schools, colleges and universities, hotels, business entities, among others.

The BSC is thus a practical framework that addresses the intangible facet of knowledge while ensuring that management investments and knowledge contribute to the strategic direction of the firm (Bose \& Thomas, 2007 ). it is evident that for BSC implementation, it is important to start with measuring the dimensions that affect the future outcomes of the company, followed by the production of effective analyses to assess the ongoing improvement towards business excellence, and ultimately, the strategic target achievement (Sarhan \& Fox, 2013).

In summary, to improve and enhance organizational performance, many strategies and practices can be implemented. It is important to manage human resource beside linking strategy with proper tool such as BSC to improve and measure performance.

\section{Objectives}

To achieve the purpose of the this study, the following objectives have been proposed:

To examine the effect of Strategic management (ST) on Organizational Performance. 
To examine the effect of Balanced scorecard (BSC) on Organizational Performance.

\section{Related Literature Review}

\subsection{Organizational Performance}

Studies dedicated to organization and humanity field are mostly focused on organizational performance because of the significance of the variable in the development of organizations, and the studies' implications on competitiveness and effectiveness of the organization.

To begin with, Combs, Crook, Shook, David and Ketchen (2005) related that in management literature, organizational performance is one of the top constructs in studies dedicated to organizations and to strategic management. In fact, in the past few years, practitioner and academic circles have forwarded innumerable studies on organizational performance to provide an insight into its processes and antecedents and to improve the organizational outcomes (Jing \& Avery, 2008).

According to Osborne and Gaebler (1992), the public sector has been interested in efficiency and effectiveness. The primary purpose behind performance management in the case of the public sector is to enhance performance, achieve objectives and clarify resources, to integrate budget cycle and policy, non-financial and financial information and to enhance accessibility, quality and information content concerning management (De Waal, 2010).

Additionally, public sector studies revealed that organizations implementing performance management have a higher tendency to offer superior services to customers, realize their objectives and enhance both efficiency and effectiveness of operations (De Waal \&Kerklaan, 2004).

The performance of the public sector differs from that of its private counterpart based on the differences in their goals and core business processes. For instance, the private sector's major aim is to achieve profit through customer value, while public sector aims to achieve quality, customer satisfaction and good performance. The latter also aims to meet the societal needs within the allocated budget (Dewhurst, Martinez-Lorente\& Dale, 1999). This is supported by Cinca, Molinero and Queiroz (2003) who described public organizations goals as more intangible compared to those of the private sector. Public administration reach and policy in the past two decades has been focused on enhancing government performance (McBride, 2008).

Organizational performance refers to the measure of the way the organization is able to manage and deliver value to its customers and stakeholders (Moullin, 2007). In another definition provided by Antony and Bhattacharyya (2010), organizational performance is a tool and measure used for the assessment and evaluation of the organization's success in creating and delivering internal and external customer value.

In the current dynamic business environment, organizational performance measurement is widely stressed for its significance in evaluating the success level of the direction of the 
strategy employed by the organization (Neely, 1999). This is because without measuring the organization's condition, it is not possible to enhance it.

\subsection{Strategy}

In the past decade, the shift in the business context has brought about the change in the management role as to how to address a challenging process (Outram, 2013). Additionally, even when organizations adopt things that align to the present market, they still fail to do so with new technology emergence (Christensen, 1997). The challenge lies in the necessity for expediency - things have to be conducted with speed as competitors, particularly with the change in the way information is used (Koch, 2011). Moreover, for sustainable business success, an effective strategy is needed and therefore, the challenge is related to how the strategy is employed (Berg \&Pietersma, 2014). This is why Koch (2011) stressed the importance of providing description and establishing the business strategy. Lastly, strategic concern is not limited to managers and entrepreneurs on the top echelons of the organization as it is also important for middle managers to understand strategy in terms of its dimensions (Johnson, Whittington \& Scholes, 2011).

The word 'strategy' stems from 'stratos', a Greek word meaning a general or a person leading the army (Matloff, 1996). The word can be traced back to the $18^{\text {th }}$ century military jargon where it is defined as a set of ideas implemented for military use to achieve strategic goals (Gartner, 1999). Stated differently, strategy refers to the art of planning and directing military actions and operations in the war (Bruce \& Langdon, 2000).

According to Kaplan and Norton (2004), because of the diverse world of business, strategy may take different definitions and adopt many frameworks. Meanwhile, Porter (1980) defined competitive strategy as the selection of different activities sets to achieve a distinct mixture of value, whereas Lynch (2007) explained it as the field of strategy management that addresses emergent and major initiatives adopted by general managers on behalf of the owners entailing the use of resources to improve firm performance in their external environment. On the other hand, Johnston, Whittington and Scholes (2011) referred to it as the organization's long-term direction, and Grant and Jordan (2013) defined it as the means to achieve objectives.

Viewed from another perspective, Steiner and Albert (1979) defined strategy as a way of acting towards the actual or predicted actions of a rival while Grant (2001) indicated that strategy is a unifying theme influencing individual and organizational actions and decisions through coherency and directions. According to Bruce and Langdon (2000), business strategy is a map of its future services and products to be marketed and the way they are launched and based on the study by McKeown (2012), it shapes the future. Finally, Kaplan and Norton (2004) defined it as a set of activities that the organization uses to stand out in the market place through sustainable distinction. 
Five forces drive the perspective of leaders to create strategy in any competitive environment and they are powerful supplies, savvy customers, new entrants, substitute and strong rivals (Porter, 2008). According to Porter (2008), savvy customers or fickle customers are constantly on the lookout for the best deals, forced low prices that leads to lowered profit.

Porter (2008) explained that the first force relates to suppliers that influence strategy by controlling profit through their high prices. The new entrant force is another force that drives business strategy as new entrants translates to new capacity and hunger for the market share. Also, substitutes have the ability to lure customers and influence strategy while established rivals promote intensive competition in terms of price and investments on products to differentiate themselves from others and hence, influence strategy. Lastly, savvy customer according to Porter (2008) is the last strategy although there are several other factors that could increase according to the firm environment, with some that could easily occur.

\subsection{Balanced Scorecard (BSC)}

The balanced scorecard was introduced by Kaplan and Norton (1992) in the early 1990s to counter the deficiencies of traditional financial performance measures in the present business environment. It is described as a multi-dimensional performance measurement system covering financial as well as non-financial measures that originate from the strategy employed by the organization and are connected through cause-and-effect relationships. More specifically, Kaplan and Norton (1992; 1996; 2001) brought forward the use of four performance dimensions, which are learning and growth perspective, internal business perspective, customer perspective and financial perspective. They claimed that ultimately, the goal of BSC implementation is to achieve superior, long-term financial outcomes.

In addition, the BSC has become an extensively known and used management tool and according to recent survey results, many organizations use or have intentions of using the BSC (Chan \& Ho, 2000; Speckbacher, Bischof \& Pfieffer, 2003). Majority of studies dedicated to BSCs involved organizations in the U.S. or Europe (Ittner \& Larcker, 2003; Speckbacher, Bichof \& Pfieffer, 2003), with little known in its use in Canada and in other countries. In Canada, it also seems that there is lack of uniformity among the 3 organizations under study in their knowledge of the term (CMA Canada, 1999). These two issues are what motivate the present study.

Kaplan and Norton's (1992) BSC has become well-known among circles of academics and practitioners. Both private and public sector companies have acknowledged and accepted the concept and used it to enhance their performance (Chan \& Ho, 2000; Hoque\& James, 2000; Ittner \& Larcker, 2003). It is however, notable that the term-balanced scorecard (BSC) has different interpretations in literature and academic studies. To begin with, Hoque and James (2000) examined the use of BSC through the use of a 20-item scale keeping in mind that it might miss the strategic relationships of a real BSC. Consequently, firms in their study may have had different BSC implementation levels that could have affected the ir outcomes, particularly because BSC usage depends on the variable in the ir regression model. Several 
other studies have used the scorecard (e.g., Chan \& Ho, 2000; Hoque \& James, 2000; Lipe \& Salterio, 2000; Malina \& Selto, 2001) and examined the judgmental effects of its information (e.g., Ittner \& Larcker, 2003; Speckbacher, Bischof \& Pfieffer, 2003). Nevertheless, only one study has tried to propose a conceptual model of the BSC in order to investigate its adoption level. Speckbacher, Bishof and Pfieffer (2003) involving Austrian, German and Swiss firms, conducted the study. This lack of studies indicates the need for more to examine the attributes of the BSC proposed by Kaplan and Norton (1992; 2001; 2006) as employed by the organizations to measure their performance.

Moreover, Kaplan and Norton (1992; 1996; 2001) stressed on the incorporation of non-financial measures as one aspect of the BSC with several structural attributes that make it distinct from the rest of the frameworks (e.g., KPI and stakeholder cards). They suggested that the BSC's distinct structure enables its use as a strategic tool to direct the organizations towards obtaining and maintaining long-term profitability. They added that non-financial metrics addition to the performance measurement system is insufficient for organizations to learn, enhance and progress. If this is so, then firms with different BSC adoption levels should face differing outcomes and thus, the authors suggested the need to conduct a comparison in terms of such differences of BSC level among companies. This would be significant if a clearly defined BSC assessment could assist in explaining the differences in results between studies.

With the interest in the BSC reaching heights over the last ten years, several authors have scrutinized its contributions to theory as well as practices; more specifically, Johnsen (2001) compared between the BSC and Management by Objectives (MBO) that was proposed by Drucker (1954). He claimed that the fundamental attributes of BSC are aligned with those of MBO. He also contended that the BSC appears to be an extension of MBO as it stresses on the feedback on outcomes through formal measurements of performance. Also, further investigation into both models (BSC and $\mathrm{MBO}$ ) revealed that they stress on tangible as well as intangible assets and the balance of the different efforts to obtain management control (Drucker, 1955; Kaplan \& Norton, 1996). However, MBO is introduced as a tool to make lower managers stand out (Drucker, 1955, p.112), while the BSC is a system used to organize managerial work at different organizational levels (Kaplan \& Norton, 1996). Another difference between the two is that in the BSC, measures are divided into perspectives but the in MBO the notion of perspectives may only be derived as every manager has to lay down his contribution to achieve the goals of the company in every business area (Drucker, 1955, p.109). Both Johnsen (2001) and Liukkonen (2000) claimed that the ideas in the BSC matches that with old management control theories on how to implement visions and strategies and the BSC is considered to be one of the current management control philosophies. The latter further stated that the new is seldom purely new but is just a classic theory wrapped and introduced in a new package. Furthermore, Liukkonen (2000) underlined the lack of theoretical basis and empirical findings of the practical use of the new philosophies that make them challenging to comprehend and use practically. In addition, Johanson, Martensson and Skoog (2001) and Otley (1999) laid emphasis on the lack of 
empirical findings and called for more examinations in organizations use of performance measurement systems. Specifically, Otley (1999) called for a case study method in single organizations to obtain insight into the use of performance measurement systems.

Several studies have suggested that measurement implementation can lead to enhanced organizational performance (e.g., Al-Ashaab, Flores, Magyar \& Doultsino, 2011; Bose \& Thomas, 2007; Bourne, Mills, Wilcox, Neely \&Platts, 2000; Niven, 2008). Therefore, it can be stated that the BSC concept reinforces the strategy and structure of the company as it provides the right information flow through the concerned people's assistance and it sheds light on the strategy implementation (Al-Ashaab, Flores, Magyar \&Doultsino, 2011; Bose \& Thomas, 2007; Bourne, Mills, Wilcox, Neely \&Platts, 2000; Niven, 2008; Al-Dhaafri \& Al-Swidi, 2014; Bose \& Thomas, 2007). Moreover, it focuses on the strategy development and the management of a set of performance measures. The BSC is thus a practical framework that addresses the intangible facet of knowledge while ensuring that management investments and knowledge contribute to the strategic direction of the firm (Bose \& Thomas, 2007).

To conclude, organizational performance measurement refers to the measurement of the way organizations are managed and their delivery of value to their stakeholders including their customers (Moullin, 2007). It consists of measurement and tools that are employed for the evaluation and assessment of the success of the organization to create and relay value to internal and external customers (Antony \& Bhattacharyya, 2010). Performance measurement primarily aims to confirm the progress towards the expected goals (Kanji \& Sa, 2007) and in this regard, several studies indicated BSC implementation to measure enhanced organizational performance (e.g., Al-Ashaab, Flores, Magyar \&Doultsino, 2011; Bose \& Thomas, 2007; Bourne, Mills, Wilcox, Neely \&Platts, 2000; Niven, 2008; Al-Dhaafri\& Al-Swidi, 2014). The BSC specifically guides the purview of business from four perspectives namely customer, internal, learning and innovation and financial perspectives (Kaplan \& Norton, 1992; Al-Dhaafri \& Al-Swidi, 2014) and it focuses on vision and strategy as opposed to control (Karanseh \& Al-Dahir, 2012).

On the basis of the above hypotheses, the following hypotheses are proposed;

H1: Strategic management (ST) has a positive and significant effect on Organizational Performance.

H2: Balanced scorecard (BSC) has a positive and significant effect on Organizational Performance.

\section{Methodology}

The present paper examines the factors in terms of their effect on other factors included in the study model (ST, BSC, OP). The study framework indicates the measurement of the effect of strategy management and balanced scorecard and their effects on the civil defense performance. The survey concerning this part of the study is categorized into two, with each 
having its own scope and representing a distinct variable. Added to the variables are some demographic questions that characterize the respondents. The first part of the survey contains demographic questions, while the second part addresses the variables to be measured.

This study employed a quantitative method by employing a survey questionnaire for data collection to measure the relationships between relevant variables (Kerlinger \& Lee, 2000). In this study, data collection method is conducted through a survey questionnaire as it is the most suitable way to gather beliefs, attitudes and personal and social facts. Added to this, a survey questionnaire method appears appropriate as the relationships are categorized as correlational/quantitative (Kerlinger \& Lee, 2000). Thus, a quantitative self-administered survey questionnaire was employed.

The balanced scorecard (BSC) is able to function as a core new management system in implementing business strategy and to bridge the gap between the strategy development and implementation that can stem from many barriers (Kaplan \& Norton, 1996). According to Kaplan and Norton, there are four specific barriers that could hinder strategy implementation namely, non-actionable vision and strategy, goals that are not linked to strategy, resource allocation that is not linked to long-term and short-term goals, and absence of strategic feedback.

The BSC was developed by Kaplan and Norton in 1992 primarily as a learning system and communication-information within businesses (Welter, Vossen, Richert\&Isenhardt, 2010).

Organizational performance measurement was taken from the studies by Narver and Slater (1990) and Jaworski and Kohli (1993). The items were measured on a 5-point Likert scale that ranges from 1 depicting strongly disagree to 5 depicting strongly agree.

\section{Data Analysis}

The data analysis method and the results are discussed and presented in the following sequence; first, the study examines the distribution of demographic variables in terms of respondents' gender, qualifications and experiences. This is followed by a discussion of the descriptive analysis of the variables and the normality testing. The Partial Least Squares Structural Equation Modeling (PLS-SEM) was employed to investigate the outer measurement model prior to examining the inner structural model and the testing of hypotheses.

The goodness of the model is linked to the study constructs which are, strategy, balanced scorecard, and organizational performance. The structural mode was examined for its quality by determining construct validity.

\section{a. Demographic Distribution of Respondents}

The final data sample was obtained from 188 participants from different units in the Northern UAE, making the percentage of respondents to be $85.5 \%$ (188 out of 220). The demographic characteristics of the respondents are displayed in Table 4.1 
Table 4.1 Demographic respondent information

\begin{tabular}{llll}
\hline Demographic & Description & Frequency & Percent \\
\hline \multirow{2}{*}{ GENDER } & Male & 182 & $96.8 \%$ \\
& Female & 6 & $3.2 \%$ \\
\hline \multirow{2}{*}{ QUALIFICATION } & Under High school & 4 & $2.1 \%$ \\
& High school & 54 & $28.7 \%$ \\
& Degree & 107 & $56.9 \%$ \\
& Post graduate & 23 & $12.2 \%$ \\
\hline \multirow{2}{*}{ EXPERIENCE } & 0-5 years & 29 & $15.4 \%$ \\
& 6-10 years & 30 & $16.0 \%$ \\
& 10 and more & 129 & $68.6 \%$ \\
\hline \multirow{5}{*}{ Place of Work } & Sharjah & 45 & $23.9 \%$ \\
& Dubai & 71 & $37.8 \%$ \\
& Ajman & 15 & $8.0 \%$ \\
& RasAlkhaimah & 20 & $10.6 \%$ \\
& Um Alqawain & 18 & $9.6 \%$ \\
\multirow{5}{*}{ Possession } & Fujairah & 19 & $10.1 \%$ \\
\hline Total Respondents & Section & 63 & $33.5 \%$ \\
& Branch & 114 & $60.6 \%$ \\
& Department & 10 & $5.3 \%$ \\
& Less than branch & 1 & $0.5 \%$ \\
\hline
\end{tabular}

\section{. Descriptive Statistics}

The study variables (organizational performance, strategy management and balanced scorecard) were described with the help of descriptive analysis. The outcome of the analysis is displayed in Table 4.2 including the mean, minimum, maximum and standard deviation of the variables. The results of the analysis reflected the level of implementation in each unit of the Northern Civil Defense in the UAE. The Likert scale was used, with the minimum value used for all framework variables being 1.00 and the maximum being 5.00.

Table 4.2 shows that the lowest standard deviation values from the perspective of the respondents is not significant different throughout the constructs dimensions. Nevertheless, it is notable that more focus is on organizational performance with a mean value of 3.782 and standard deviation of 0.753 . The respondents stressed on the implementation of organizational performance in their units by raising their level of unit performance.

Table 4.2 Descriptive Statistics of the Constructs

\begin{tabular}{llllll}
\hline Construct & $\mathrm{N}$ & Minimum & Maximum & Mean & $\begin{array}{l}\text { Std. } \\
\text { Deviation }\end{array}$ \\
\hline OP & 188 & 1 & 5 & 3.782 & 0.753 \\
ST & 188 & 1 & 5 & 3.760 & 0.853 \\
BSC & 188 & 1 & 5 & 3.624 & 0.743 \\
\hline
\end{tabular}

c. The Construct Validity

Construct validity refers to the level to which test measures applied measures what they claim to measure - reflecting the integrity between the theoretical and operational frameworks (Trochim, 2006). Hair et al. (2010) stated that construct validity can be gauged through the 


\section{Macrothink}

Business Management and Strategy

ISSN 2157-6068

2018, Vol. 9, No. 1

implementation of the content validity, discriminate validity and convergent validity at the same time.

\section{i. Content Validity}

Content validity refers to the level to which the measurement item reflects the concept of a construct (Hair, Anderson, Tatham \& Black, 2010; Pennington, 2003). The review of literature and the factor analysis of the model variables show that the entire items making up the research model are assigned appropriately to their respective constructs. The items loaded to their respective constructs compared to others and the items loaded significant on the same ensuring the measures content validity (Chow \& Chan, 2008) as presented in Table 4.3.

Table 4.3 Factor Analysis and Items Loadings (Correlation)

\begin{tabular}{lllll}
\hline Construct & Item & OP & ST & BSC \\
\hline \multirow{4}{*}{ OP } & OP1 & $\mathbf{. 8 1 3}$ & .456 & .501 \\
& OP2 & $\mathbf{. 8 1 4}$ & .498 & .539 \\
& OP3 & $\mathbf{. 7 8 6}$ & .326 & .402 \\
& OP4 & $\mathbf{. 8 1 4}$ & .556 & .620 \\
& ST1 & .552 & $\mathbf{. 8 2 8}$ & .659 \\
& ST2 & .389 & .745 & .579 \\
& ST3 & .466 & $\mathbf{. 7 6 7}$ & .574 \\
& ST4 & .435 & $\mathbf{. 7 8 1}$ & .615 \\
ST & ST5 & .349 & $\mathbf{. 6 9 3}$ & .521 \\
& ST6 & .401 & $\mathbf{. 6 9 4}$ & .507 \\
& ST7 & .464 & $\mathbf{. 8 0 1}$ & .586 \\
& ST8 & .454 & .728 & .612 \\
& ST9 & .413 & $\mathbf{. 7 8 7}$ & .655 \\
& ST10 & .427 & $\mathbf{. 8 0 5}$ & .680 \\
& BSC1 & .473 & .548 & $\mathbf{. 7 6 5}$ \\
& BSC2 & .508 & .499 & $\mathbf{. 6 8 8}$ \\
BSC & BSC3 & .499 & .565 & $\mathbf{. 7 6 5}$ \\
& BSC4 & .467 & .559 & $\mathbf{. 7 3 0}$ \\
& BSC5 & .545 & .677 & $\mathbf{. 8 4 1}$ \\
& BSC6 & .504 & .696 & $\mathbf{. 8 4 6}$ \\
& BSC7 & .513 & .652 & $\mathbf{. 7 7 5}$ \\
& BSC8 & .560 & .639 & $\mathbf{. 8 1 4}$ \\
& BSC9 & .421 & .626 & $\mathbf{. 7 6 9}$ \\
& BSC10 & .555 & .706 & $\mathbf{. 8 4 9}$ \\
\hline
\end{tabular}

ii. Convergent Validity Analysis

Hair et al. (2010) referred to convergent validity as the level to which a group of variables are closes in the concept of measuring a certain item. It indicates the level to which the construct items are related to each other in measuring a construct (Trochim, 2006). Based on Hair et al.'s (2010) argument, three conditions have to be met to establish convergent validity namely, composite reliability (CR), factor loadings and average variance extracted (AVE). The relationship between the items can be confirmed if the correlation reading falls in the range of -1.00 to +1.00 as established by Trochim (2006). Thus, according to multivariate analysis literature, the entire items examined were found to be within the acceptable range (Hair et al., 2010). 


\section{Macrothink}

The factor loadings are significant at the significance level of 0.01 . Moving on to the second condition for convergent validity testing, composite reliability is described as the level of the consistent represent of the latent construct by the items (Hair et al., 2010).

The values of composite reliability and Cronbach's alpha are obtained and presented in Table 4.4 through SPSS statistics. The Cronbach's alpha values fell in the range of 0.822 to 0.946 and the CR values in the range of 0.881 to 0.953 indicating that the values exceeded the value of 0.7 (Fornell \& Larcker, 1981; Hair, 2010).

Therefore, the convergent validity of the outer model is confirmed. This is further supported by the average variance extracted (AVE) values that reflect the extracted average variance among items groups based on their relationship with the shared variance, with the measurement errors. AVE gauges the indicators obtained variance and link the appropriated variance to the measurement errors.

Lastly, if the value of AVE exceeds 0.5, this shows that he used items sets to measure construct are converged sufficiently (Barclay et al., 1995). In the context of this study, the AVE values ranged from 0.536 to 0.650 , indicating good construct validity level of the measures (Barclay, Higgins \& Thompson, 1995).

Table 4.4 Convergent Validity \& Significance of Factor Loading

\begin{tabular}{|c|c|c|c|c|c|c|}
\hline Construct & Item & Loading & T-value & CR & Cronbach alpha & AVE \\
\hline \multirow{4}{*}{$\mathrm{OP}$} & OP1 & 0.813 & 18.856 & \multirow{4}{*}{0.881} & \multirow{4}{*}{0.822} & \multirow{4}{*}{0.650} \\
\hline & OP2 & 0.814 & 15.332 & & & \\
\hline & OP3 & 0.786 & 10.380 & & & \\
\hline & OP4 & 0.814 & 21.707 & & & \\
\hline \multirow{10}{*}{ ST } & ST1 & 0.828 & 31.272 & \multirow{10}{*}{0.933} & \multirow{10}{*}{0.920} & \multirow{10}{*}{0.584} \\
\hline & ST2 & 0.745 & 13.288 & & & \\
\hline & ST3 & 0.767 & 16.356 & & & \\
\hline & ST4 & 0.781 & 16.161 & & & \\
\hline & ST5 & 0.693 & 8.503 & & & \\
\hline & ST6 & 0.694 & 9.152 & & & \\
\hline & ST7 & 0.801 & 21.260 & & & \\
\hline & ST8 & 0.728 & 10.579 & & & \\
\hline & ST9 & 0.787 & 19.159 & & & \\
\hline & ST10 & 0.805 & 17.777 & & & \\
\hline \multirow{10}{*}{ BSC } & BSC1 & 0.765 & 13.755 & \multirow{10}{*}{0.942} & \multirow{10}{*}{0.931} & \multirow{10}{*}{0.618} \\
\hline & BSC2 & 0.688 & 12.292 & & & \\
\hline & BSC3 & 0.765 & 14.846 & & & \\
\hline & BSC4 & 0.730 & 12.804 & & & \\
\hline & BSC5 & 0.841 & 22.678 & & & \\
\hline & BSC6 & 0.846 & 25.969 & & & \\
\hline & BSC7 & 0.775 & 12.094 & & & \\
\hline & BSC8 & 0.814 & 20.496 & & & \\
\hline & BSC9 & 0.769 & 14.057 & & & \\
\hline & BSC10 & 0.849 & 26.402 & & & \\
\hline
\end{tabular}

iii. Discriminant Validity Analysis

In order to confirm the validity of the constructs within the model, it is crucial to confirm the 
model's discriminant validity - this is a mandatory test prior to the hypotheses testing. In particular, discriminant validity measures the differentiating degree of the items among the constructs. This test ensures that no relationship exists between the unrelated items. It also measures the shared variance within a construct that should be higher compared to the variance shared among the other constructs (Compeau, Higgins \& Huff, 1999). In this study, discriminant validity of the model is confirmed through Fornell and Larcker's (1981) method.

The AVE square root of the all the constructs in Table 4.5 is replaced at the correlation matrix. The study's outer model's discriminant validity is confirmed as the related attributes in the table and the carry items for the related construct exceeded the other elements of the column below the other constructs. The validity results of the model confirmed the model items validity as well as reliability.

Table 4.5 The Discriminant Validity Matrix using PLS

\begin{tabular}{llll}
\hline & BSC & OP & ST \\
\hline BSC & 1 & & \\
OP & 0.653148 & 1 & \\
ST & 0.785135 & 0.584247 & 1 \\
\hline
\end{tabular}

d. Hypotheses Testing Procedures

The PLS Algorithm using Smart PLS is used to testing the hypothesized model, where Figure 4.1 illustrates the path coefficients generation as suggested by Yetton et al. (2000), Shenhar et al. (2001) and Bourne et al. (2000).

Table 4.6 The Results of the Inner Structural Model

\begin{tabular}{lllllll}
\hline Hypothesis & Relation & $\begin{array}{l}\text { Path } \\
\text { Coefficient }\end{array}$ & $\begin{array}{l}\text { Standard } \\
\text { Error }\end{array}$ & $\begin{array}{l}\text { T } \\
\text {-value }\end{array}$ & P-Value & Decision \\
\hline H2 & ST -> OP & 0.587 & 0.066 & 8.894 & 0.000 & Supported \\
H3 & BSC $\rightarrow$ & 0.654 & 0.061 & 10.765 & 0.000 & Supported \\
\hline
\end{tabular}

${ }^{*}: \mathrm{p}<0.5 ;{ }^{* *}: \mathrm{p}<0.01 ; * * *: \mathrm{p}<0.001$

\section{e. The Predictive Relevance of the Model}

Studies dedicated to multivariate data analysis stated that $\mathrm{R}$ square of the endogenous variables is explained by the predictor variables. It can therefore be stated that the $\mathrm{R}$ squares magnitude of the endogenous variables indicate the model's predictive power. The method of reusing sample adopted from Stone (1975) and Geisser (1975) was employed to confirm the model's predictive validity in this study. Wold (1982) argued that PLS is suitable to be used for the sample's reuse technique (Gotz, Liehr-Gobbers\&Krafft, 2011).

\section{i. Cross-Validated Redundancy}

The predictive relevance of the model can be tested using the Stone-Geisser non-parametric test as evidenced by Chin (1998), Fornell and Cha (1994), Geisser (1975) and Stone (1975). The blindfolding procedure in the PLS package can be utilized for the examination of the 
predictive ability of the model. Such procedure is created to get rid of some data while handling them as missing values to estimate parameters. The estimated parameters are then utilized to recreate raw data that have earlier been missed. A general cross-validating metrics $\left(\mathrm{Q}^{2}\right)$ is produced as the outcome of the blindfolding process.

There are different forms of $\left(\mathrm{Q}^{2}\right)$ that can be obtained on the basis of the chosen prediction form. More importantly, a cross-validated communality is acquired when the data points are predicted using the underlying latent variable scores. On the other hand, if the data points prediction is acquired by the latent variables predicting the block, then a cross-validated redundancy $\left(\mathrm{Q}^{2}\right)$ is the result.

Moreover, the cross-validated redundancy measure can be deemed to be capable of indicating the model's predictive relevance (Fornell \& Cha, 1994). If the redundant communality is found to exceed 0 for all the endogenous variables, the model is deemed to own predictive validity and if otherwise, its predictive relevance is inconclusive (Fornell \& Cha, 1994).

The cross-validated redundancy for organizational performance is 0.275 (See Table 4.7), and based on the above condition provided by Fornell and Cha (1994), the model has adequate predictive validity.

Table 4.7 Predictive Quality Indicators of the Model

\begin{tabular}{lllll}
\hline Variable & $\begin{array}{l}\text { Variable } \\
\text { Type }\end{array}$ & R square & $\begin{array}{l}\text { Cross-Validated } \\
\text { Communality }\end{array}$ & $\begin{array}{l}\text { Cross-Validated } \\
\text { Redundancy }\end{array}$ \\
\hline Organizational Performance & Endogenous & 0.430 & 0.629 & 0.275 \\
\hline
\end{tabular}

f. The Goodness of Fit (GoF) of the Whole Model

Contrasting to CBSEM, PLS-SEM uses only a single measure for goodness of fit. According Tenenhaus et al. (2005), goodness of fit for PLS refer to the geometric mean of the average communality and the average $\mathrm{R}$ square of the endogenous variables. As such, GoF measure constitutes the variance extracted by the inner as well as the outer model. Wetzels, Odekeren-Schroder and Van Oppen (2009) established guidelines using the following formula;

$$
\begin{gathered}
\text { Gof }=\sqrt{\left(\overline{R^{2}} \times \overline{A V E)}\right.} \\
\text { Gof }=\sqrt{(0.573 \times 0.750}=0.558
\end{gathered}
$$

Thus, the comparison was conducted on the basis of the baseline values of GoF laid down by Wetzels et al. (2009) which is as follows 0.1 denotes small, 0.25 denotes medium while 0.36 denotes large. The GoF result of the model is large based on the above values, which shows 
adequate PLS model validity.

\section{Discussion and Conclusion}

The primary aim of this study is to examine the effect of strategy and balanced scorecard (BSC) on organizational performance (OP). This study examined the relationship between strategy management and organizational performance and the findings indicated positive and significant effect at $(\beta=0.0 .587, \mathrm{t}=8.894, \mathrm{p}<0.001)$. This finding is aligned with prior studies in literature (e.g., Nilsson \&Olve, 2001; Thomas, 2007; Bourne et al., 2000; Kaplan \& Norton, 2007).

The results also showed a positive and significant effect of BSC on organizational performance at $(\beta=0.654, \mathrm{t}=10.765, \mathrm{p}<0.001)$ - a finding consistent with reported findings from literature (e.g., Bose \& Thomas, 2007; Serra \& Kunc, 2015; Sarhan \& Fox, 2013; Neilsen \& Nielsen, 2015; Cooke-Davies, 2002; Westerveld, 2003).

In sum, the civil defense performance in the UAE will remain a top issue when it comes to the development of the country. It is thus crucial for the departments making up the civil defense to assist in the achievement of the country's goals and objectives. Prior studies have extensively acknowledged the key role of SM and BSC as effective strategies that are invaluable to improve organizational performance and competitive advantage.

This study reached results that supported and rejected the hypotheses proposed concerning the effect of SM and BSC, indicating the variables importance and significant impacts or lack thereof on organizational performance. Although the strategies are adopted form the West, they can be invaluable to developing countries as well for the enhancement of organizational performance, specifically the UAE public organizations in general and civil defense.

Several insights into the issues relating to the UAE civil defense performance are highlighted in this study. To date, this study is the only one conducted in the Middle East and the Arab world that investigated the joint effect of ST and BSC on organizational performance. Through such integration, this study is expected to contribute to both literature and practice. Some of these contributions are explained in the next sub-section.

This study shed more light on the understanding of the relationship between the study variables (i.e. ST, BSC and organizational performance). The study's framework is developed based on the results of prior studies in literature and is used to examine the proposed hypotheses. The study significance is presented in the first chapter, while the contributions are provided in this sub-section.

First, this study found ST significant in improving organizational performance as the effect of ST on the same was not confirmed. Some studies reported a positive and significant of ST dimensions on organizational performance, while others did not and thus, attributed to the collapse of organizations (e.g., Hunton et al., 2003; Velcu, 2007; Wieder, Booth, Matolcsy \& Ossimitz, 2006). 
Second, this study confirmed the significance of BSC for the performance of the departments of Civil Defense - this contributed to confirming the relationship as literature reported inconsistent results of the same relationship. The inconclusive results in this regard made practitioners and academics doubt the appropriateness of BSC for organizational performance (Wiklund \& Shepherd, 2005) but the findings provided in this study confirmed its positive significant impact on performance.

Fourth, this study found the joint effect of ST and BSC on organizational performance to be stronger than their individual effects. It suggests that the variables should be implemented as integrated strategies and this is further evidenced by the inter-dependence of the constructs dimensions. To this end, when the impact of the variables as composite variables is compared with the impact of their dimensions on organizational performance, the findings indicated their effective use as bundles as opposed to groups of strategies and practices.

Fifth, a number of previous studies focused on the manufacturing and service sectors but this study extended literature concerning the study variables by focusing on the UAE Civil Defense departments, sectors and branches. This is a significant contribution as most of the studies in the public sector, particularly the Civil Defense departments were conducted as conceptual, observational and descriptive studies. Hence, this study contributes as an empirical study to literature dedicated to Northern UAE Civil Defense.

Lastly, this study tested the hypotheses and the model and carried out a robust analysis of the validation instrument. Studies in literature largely dependence on the traditional instrument validation (e.g., factor analysis and Cronbach's alpha coefficient) - these instruments are not enough to handle complex analysis. Therefore, in this study, the researcher employed PLS-SEM for the validation of the measurement model and testing the proposed hypotheses. To the best knowledge of the researcher, this study is one of the few that used such an approach to analyze the goodness of fit of the model and for testing the hypotheses.

\section{Recommendations and Suggestions}

According to the results of this study, strategic management and BSC were found to have a significant effect on organizational performance. The importance of strategic management and BSC were highlighted for more effective performance due to their roles in enhancing the overall performance that lead organizations to achieve their objectives. It is great to mention that the current study was in public section especially in civil defense which is one of this study's limitation, therefore, it is suggested to include in the future other organizations in public and private sectors.

\section{References}

Anthony, W., Kacmar, K., \& Perrewe, P. (2002). Human resources management: A strategic approach (4th ed.). Harcourt College Publisher.

Antony, J. P., \& Bhattacharyya, S. (2010). Measuring organizational performance and organizational excellence of SMEs - Part 2: an empirical study on SMEs in India. Measuring 
Business Excellence, 14(3), 42-52.

Armstrong, M. (2000). Strategic human resources management: A guide to action . British Library Catalouging.

Askov, E. (2000). Workplace literacy: evaluation of three model programs. Adult Basic Education, 10, 100-108.

Azhar, K., \& Faruq, A. (1999). Historical evolution of strategic human resource management. Malaysia Management Review, 11-23.

Bamberger, P., \& Meshoulam, H. (2014). Human Resource Strategy: Formulation, Implementation, and Impact. New York and London: Routledge.

Barclay, D., Higgins, C., \& Thompson, R. (1995). The partial least squares (PLS) approach to causal modeling: personal computer adoption and use as an illustration. 2(2), 285-309.

Barney, J. (1986). Organizational culture: can it be a source of sustained competitive advantage? Academy of Management Review, 11, 656-65.

Barney, J. (1991). Firm resources and sustained competitive advantage. Journal of Management., 17(1), 99-120.

Berg, G. V., \& Pietersma, P. (2014). The 8 Steps to Strategic Success: unleashing the power of engagement. London, UK: Kogan Page Limited.

Bourne, M., Mills, J., Wilcox, M., Neely, A., \& Platts , K. (2000). Designing, implementing and updating performance measurement systems. International Journal of Operations \& Production Management., 20(7), 754-771.

Bruce, A., \& Langdon, K. (2000). Strategic thinking. London: Dorling Kindersley Ltd.

Bryde, D. J. (1997). Underpinning modern project management with TQM principles. The TQM Magazine., 9(3), 231-238.

Certo, S. (2003). Modem management. New Jersey: Prentice Hall.

Chang, W., \& Huang, T. (2005). Relationship between strategic human resources management and firms performance. International Journal of Manpower, 26(5).

Chow, W. S., \& Chan, L. (2008). Social network, social trust and shared goals in organizational knowledge sharing. Information \& Management, 45(7), 458-465.

Christensen, C. M. (1997). The Innovator's Dilemma: When New Technologies Cause Great Firms to Fail, The Management of Innovation and Change Series. Boston: MA: HBS Press.

Cinca, C. S., Molinero, C. M., \& Queiroz, A. B. (2003). The Measurement of Intangible Assets in Public Sector Using Scaling Techniques. Journal of Intellectual Capital, 4(2), 249-275. 
Combs, J. G., Crook, T. R., Shook, C. L., David, J., \& Ketchen, J. A. (2005). The Dimensionality of Organizational Performance and its Implications for Strategic Management Research. Research Methodology in Strategy and Management, 2, 259-286.

Compeau, D., Higgins, C. A., \& Huff, S. (1999). Social Cognitive Theory and individual Reactions to Computing Technology - A Longitudinal-Study. MIS quarterly, 23(2), 145-158.

Cooke, F. L., Shen, J., \& McBride, A. (2005). Outsourcing Human Resource as a Competitive Strate'gy. Human Resource Management Journal., 44(4), 413-432.

Cooper, D. R., \& Schindler, P. S. (2006). Business Research Methods (9th ed.). (9th ed.). New York: McGraw-Hill.

David, W., Chin, H., \& Victor, K. (2002). Strategic human resource management and organizational performance in Singapore. . Compensation and Benefits Review, 34, 33-42.

De Waal , A. D. (2010). Achieving high Performance in the Public Sector What needs to be Done? Public Performance \& Management Review, 34(1), 81-103.

Delaney, J., \& Huselid, M. (1996). The impact of human resource management practices on perceptions of organizational performance. Academy of Management Journal, 39, 949-969.

Delery, T., \& Doty, D. (1996). Modes of theorizing in strategic human resource management: test of universalistic, contingency and configurational performance predictions. Academy of Management Journal, 39(4), 802-835.

Dewhurst, F., Martínez-lorente, A. R., \& Dale, B. (1999). TQM in public organisations : an examination of the issues. Managing Service Quality, 9(4), 265-273.

Drucker, P. F. (1955). The Practice of Management. London: The Heinemann Group.

Dyer, L., \& Reeves, T. (1994). Human resource strategies and firm performance: What do we know and where do we need to go? Center for Advanced Human Resource Studies.

Fornell, C., \& Larcker, D. F. (1981). Evaluating structural equation models with unobservable variables and measurement error. Journal of Marketing Research, 18(1), 39-50.

Gartner, S. S. (1999). Strategic Assessment in War. New Haven and London: Yale University Press.

Grant, R. M., \& Jordan, J. (2013). Foundations of Strategy. Chichester, UK: John Wiley \& Sons Ltd.

Gratton, L., Hope-Hailey, V., Stiles, P., \& Truss, C. (1999). Linking individual performance to business strategy: The people process model. Human Resource Management, 1, 17-31.

Guest, D. E. (1997). Human resource management and performance: a review and research agenda. International Journal of Human Resource Management, 8(3), 263-76.

Hair, J. F., Anderson, R. E., Tatham, R. L., \& Black, W. C. (2010). Multivariate Data Analysis 
(7th ed.). New Jesey: Prentice Hall.

Hoque, Z., \& James, W. (2000). Linking Balanced Scorecard measures to size and market factors: Impact on organizational performance. Journal of Management Accounting Research, 12, 1-17.

Huselid, M. (1995). The impact of human resource management practices on turnover, productivity, and corporate financial performance. Academy of Management Journal, 38, 635-672.

Huselid, M., \& Becker, B. (1996). Methodological issues in cross-sectional and panel estimates of the human resource- firm performance link. Industrial Relations, 35, 400-22.

Ittner, C. D., \& Larker, D. F. (2003). Coming Up Short on Nonfinancial Performance Measurement. Harvard Business Review, 1-9.

Jackson, S., \& Schuler, R. (. (1995). Understanding human resource management in the context of organizations and their environments. Annual Review of Psychology, 46, 237-264.

Jing, F. F., \& Avery, G. C. (2008). Missing Links in Understanding the Relationship between Leadership and Organizational Performance. International Business \& Economics Research Journal, 7(5), 67-78.

Johnsen, A. (2001). Balanced scorecard: theoretical perspectives and public management implications. Managerial Auditing Journal, 319-330.

Johnson, G., Whittington, R., \& Scholes, K. (2011). Exploring Strategy (Ninth ed.). London, UK: Pearson.

Kaplan, R. S., \& Norton, D. P. (1992). The Balanced Scorecard - Measures that Drive Performance. Harvard Business Review, 70-79.

Kaplan, R. S., \& Norton, D. P. (1996). The Balanced Scorecard: Translating strategy into action. Boston: Management: Harvard Business School Press.

Kaplan, R. S., \& Norton, D. P. (2004). Strategy Map : converting intangible assets into tangible outcomes. Boston, US: Harvard Business School Publishing Corporation.

Kerlinger, F. N., \& Lee, H. B. (2000). Foundations of behavioral research (4th ed.). Orlando, US: Harcourt College Publishers.

Koch, R. (2011). Strategy : How to create, Pursue and deliver a winning strategy (Fourth ed.). Edinburgh Gate, UK: Pearson Education Ltd.

Kochan, T., \& Dyer, L. (1993). Managing Transformational Change: the Role of Human Resource Management. International Journal of Human Resource Management., 15(4), 555-568.

Lado, A., \& Wilson, M. (1994). Human Resource systems and sustained competitive 
advantage: A competency based perspective. Academy of Management Review, 19(4), 699-727.

Lain, H. (2011). Human Resource Management for MBA students (2nd ed.). London: Chartered Institute of Personnel Development.

Lee, F. H., Lee, T. Z., \& Wu, W. (2010). The relationship between human resource management practices, business strategy and firm performance: evidence from steel industry in Taiwan. The International Journal of Human Resource Management, 21(9), 1351-1372.

Lipe, M., \& Salterio, S. (2000). The BSC: Judgmental Effects of Common and Unique Performance Measures. . The Accounting Review, 75(3), 283-296.

Lipe, M., \& Salterio, S. (2002). A note on the judgmental effects of the balanced scorecard's information organization. Accounting, Organizations and Society, 27, 531-540.

Liukkonen, P. (2000). Verksamhetsuppföljning med inriktning på personalen, ekonomin och organisationen§. Norsborg, Oskar Media. Malmi, T.

Lynch, R. (2007). Strategic Management (6th ed.). UK: Pearson.

Malina, M., \& Selto, F. (2001). Communicating and controlling strategy: An empirical study of the effectiveness of the Balanced Scorecard. Journal of Management Accounting Research, 13, 47-90.

Martell, K., \& Carroll, S. J. (1995). How strategic is HRM? Human Resources Management, 34(2), 253-267.

Matloff, M. (1996). AMERICAN MILITARY HISTORY - Volume 1: 1775-1902. United Kingdom: Combined Books Pennsylvania.

McBride, H. (2008). J. Cell Biol., 183, 757-759.

Mckeown, M. (2012). The Strategy Book. Edinburgh Gate: Pearson Education Limited.

Moullin, M. (2007). Performance measurement definitions: Linking performance measurement and organisational excellence. International Journal of Health Care Quality Assurance, 20(3), 181-183.

Nankervis, A., Compton, R., \& Savery, L. (2002). Strategic human resources management in small and medium entreprises: A CEO's Perspective? Asia Pacific journal of Human Resources, 40(2), 260-273.

Neely, A. (1999). The performance management revolution: why now and what next. International Journal of Operations \& Production Management, 19(2), 205-228.

Nigam, A. K., Nongmaithem, S., Sharma, S., \& Tripathi, N. (2011). The impact of strategic huma re source management on the performance of firms in India: A study of service sector firms. Journal of Indian Business Research, 3(3), 148-167. 


\section{Macrothink}

Business Management and Strategy

ISSN 2157-6068

2018, Vol. 9, No. 1

Osborne, D., \& T. Gaebler. (1992). Reinventing Government. How the Entrepreneurial Spirit is Transforming the Public Sector. Addison-Wesley, Reading, MA.

Osterman, P. (1994). How common is workplace transformation and who adopts it?. Industrial and Labour Relations Review, 47, 173-88.

Otley, D. (1999). Performance management: A framework for management control system approach. Management Accounting Research., 10, 363-382.

Outram, C. (2013). Making your strategy work: how to go from paper to people. Edinburgh Gate, UK: Pearson Education Limited.

Pennington, D. (2003). Essential Personality. Arnold. ISBN 0-340-76118-0, 37.

Pfeffer, J. (1994). Competitive Advantage Through People. California Management Review, $36(2)$.

Porter, M. (1980). Competitive strategy. Boston: New York: Free Press.

Porter, M. E. (2008). The Five Competitive Forces that shape strategy. Harvard Business Review, 86(1), 78-93.

Richard, O. C., \& Johnson, N. B. (2001). Strategic human resource management effectiveness and firm performance. International Journal of Human Resource Management, 12(2), 299-3 10.

Singh, K. (2004). Impact of HR practices on perceived firm performance in India. Asian Pacific Journal of Human Resources, 42, 301-317.

Speckbacher, G., Bischof, J., \& Pfieffer, T. (2003). A Descriptive Analysis on the Implementation of Balanced Scorecards in German-speaking Countries. Management Accounting Research, 14, 361-387.

Steiner, \& Albert, G. (1979). Strategic Planning. New York: Free Press.

Trochim, W. M. (2006). Web Center for Social Research Methods. Retrieved June 2, 2014, from http://www.socialresearchmethods.net/kb/convdisc.php

Truss, C., \& Gratton, L. (1994). Strategic human resource management: A conceptual approach. International Journal of Human Resource Management, 5(3), 663-686.

Ulrich, D., \& Lake, D. (1991). Organizational capability: Creating competitive advantage. Academy of Management Executive, 5(77).

Waiganjo, E. W., Mukulu, E., \& Kathiri, J. (2012). Relationship between Strategic Human Resource Management and Firm Performance of Kenya 's Corporate Organizations School of Human Resource Development. International Journal of Humanities and Social Science, 2(10), 62-70.

Wan, D., Kok, V., \& Ong, C. H. (2002). Strategic Human Resource Management and 


\section{Macrothink}

Organizational Performance in Singapore. Singapore H R Management, 33-42.

Welbourne, T., \& Cyr, L. (1999). The human resource executive effect in initial public offering firms. Academy of Management Journal, 42, 616-629.

Wright, P. M., \& McMahan, G. (1992). Theoretical Perspectives for Strategic Human Resource Management. Journal of Management, 18(2), 295-320.

Wright, P. M., \& Snell, S. (1998). Toward a unifyrng framework for exploring fit and flexible in strategic human resource management. . Academy of Management Review, 23, 756-772.

Wright, P., \& McMahan, G. (1994). McWilliams Human resources and sustained competitive advantage: a resource-based perspective. The International Journal of Human Resource Management, 5(2), 301-326.

Wright, P., Dunford, B., \& Snell, S. (2001). Human resources and the resource based view of the firm. Journal of Management, 27(6), 701-721.

Zikmund, G. W. (2003). Business Research Methods. Oklahoma: South-Western.

\section{Copyright}

Copyright for this article is retained by the author(s), with first publication rights granted to the journal.

This is an open-access article distributed under the terms and conditions of the Creative Commons Attribution license (http://creativecommons.org/licenses/by/4.0/). 